\title{
Individualism in African Moral Cultures
}

\author{
Motsamai MOLEFE \\ University of Kwa-Zulu Natal, Research Institute \\ New Arts Building, Room 307, Pietermaritzburg, South Africa \\ motsaik@yahoo.com
}

\begin{abstract}
This article repudiates the dichotomy that African ethics is communitarian (relational) and Western ethics is individualistic. 'Communitarianism' is the view that morality is ultimately grounded on some relational properties like love or friendship; and, 'individualism' is the view that morality is ultimately a function of some individual property like a soul or welfare. Generally, this article departs from the intuition that all morality including African ethics, philosophically interpreted, is best understood in terms of individualism. But, in this article, I limit myself to the literature in the African moral tradition; and, I argue that it is best construed in terms of individualism contrary to the popular stance of communitarianism. I defend my view by invoking two sorts of evidences. (1) I invoke prima facie evidence, which shows how both secular and religious moral thinkers in the tradition tend to understand it in individualistic terms. And, (2) I invoke concrete evidence, I show that the two terms that can be said to be definitive features of African ethical framework, namely: personhood and dignity, are individualistic. I conclude by considering possible objections against my defense of individualism as a central feature of African ethics.

Keywords: African Ethics, Communitarianism, Dignity, Individualism, Personhood, Relationalism
\end{abstract}

\section{INTRODUCTION}

One of the perennial debates in African philosophy pertains to the relationship between the community and an individual. This debate can be framed in different ways. One can frame it in hierarchical terms where they consider the question of which between the two takes priority, the community or individual. In the literature, this debate plays itself out between the so called 'radical' and 'moderate' communitarians (Menkiti, 1984; Gyekye, 1992; 1997). Whereas Ifeanyi Menkiti appears to be placing priority on the community; Gyekye places it on neither, he considers them to be equally fundamental. But commentators in the literature converge on the idea that Gyekye's moderate communitarianism also ends up prioritizing the community over the individual (Matolino, 2009; 
Famanikwa, 2010). If this reading of Gyekye is correct then it reveals the stubbornness of the priority of the community in African thought ${ }^{1}$.

This question can also be framed in terms of where to ultimately locate moral value: (1) in some individual property (individualism) or (2) some communal one (communitarianism)? Much of the literature seems to think that African moral thought is best construed in terms of locating it in some communal property rather than an individual one i.e., communal properties, in moral theorization, ought to take priority over individual ones (Ramose, 1999; Murove, 2004; Metz, 2007). This prioritization of the communal moral properties over individual ones is unsurprising given that African moral cultures are usually represented in the literature in terms of communitarianism as opposed to Western one's that are typically designated in terms of individualism (Shutte, 2001; Bujo, 2001; Mbigi, 2005). Gyekye (1992: 102) captures the importance of communal features by noting that they are not "only its outstanding features, but its defining characteristics".

In this article, I seek to argue that African moral cultures are more individualistic than we have been made to believe by scholars in the tradition. This is largely a moral project since I will be considering the question of where ultimately to locate moral value by analyzing what intellectuals in an African tradition have had to say ${ }^{2}$. And, I will show that consistently African scholars have located it in individual properties. Further, I will show that even those who overtly attempt to argue for non-individualistic approaches ultimately revert back to them, somehow. The novel claim defended in this article is that individualism is an inevitable and inescapable in moral philosophy, be it Western or African; but, in this article, I will limit my focus to the literature in the African moral tradition ${ }^{3}$.

Other scholars have noted that there are strands of individualism in African moral thought. For example, Kevin Behrens (2011), writing in a context of defending an African environmental ethics, notices some strands of individualism in African moral thought; but he ultimately favors a communalistic account of it. Thad Metz (2007) in his influential article "Toward an African Moral Theory" had indicated that in his survey of the literature in African moral thought, he had discovered that much of it takes an individualist orientation, but he goes on to defend a community-based moral theory as the most plausible way to understand African ethics (Metz, 2007; 2010). 
Though these scholars rightly pick up some traces of individualism in an African tradition, they ultimately berate them as implausible attempts to capture African moral thought. This article differs from these attempts by insisting on individualism as a crucial or defining feature of African ethics. The reason why I take such a stance is that I believe that all morality ultimately is about individuals and their own lives in a social context. The social context occasions morality insofar as certain forms of social life are conducive for human (individual) life (right/good) and others are not (wrong/bad). So, morality is a servant of individuals rather than individuals being servants of it.

To defend the essential individualism that characterizes African moral thought, I appeal to two central ethical terms in African moral thought, namely: personhood and dignity. Personhood is understood to be definitive of African moral thought (Masolo, 2010). In fact Gyekye notes:

"With all this said, however, this aspect of this account adumbrates a moral conception of personhood and is, on that score, interesting and relevant to the notion of personhood important for the communitarian framework." (Gyekye, 1997: 64)

So, here we are informed that the notion of personhood is important to a communitarian framework. In fact, Wiredu explicitly informs us that to understand values that embody communitarianism we have to study this notion of personhood (2008: 336). Another crucial notion in African thought is that of dignity. 'Dignity' refers to beings that have inherent moral worth that are deserving of our utmost moral respect (Gyekye, 1992; Ilesanmi, 2001). These two notions are thought to be essential components of the Afro-communitarian architecture so much that without them it will crumble or will be deformed beyond recognition. My argument is that taking these moral terms seriously commits us to locate the ultimate value in some individual property rather than a communal one. This conclusion may strike some as bizarre, but it is not absurd to think that communitarianism is an individualistic morality like all morality is.

To defend individualism in Afro-communitarian morality, I structure this article as follows. Firstly, I distinguish between individualism and communitarianism. The success of this article, will in part, depend on the correct use of these two terms. Secondly, I provide prima facie evidence that points to individualism in African moral thought by considering 
works of influential moral thinkers like Kwasi Wiredu and Kwame Gyekye, among others. This prima facie evidence strongly points to the prominence of individualism. I proceed next to demonstrate that commitment to the ideas of 'personhood' and dignity renders Afro-communitarianism to be founded on moral individualism. Finally, I conclude by considering objections against my defense of individualism, drawn mainly from Thad Metz's influential African relational moral theory.

\section{INDIVIDUALISM AND COMMUNITARIANISM}

In this section, I clarify how the ideas of individualism and communitarianism are used in this article. 'Individualism' refers to those moral theories that ultimately ground morality on some properties intrinsic to an individual like welfare, soul, rights (Behrens, 2011). For example, influential moral theories in the West like Utilitarianism and Kant's deontology usually takes an individualist frame in the sense defined here. Utilitarianism, for example, considers welfare construed as pleasure or informed preference on these intrinsic features of an individual (Singer, 1989: 150). Or, even Kant's deontology explains right/wrong actions in terms of whether they honor or undermine the individual's autonomy, a feature that is internal to an individual. So, wrong actions have an essential feature of harming or undermining some property of an individual ${ }^{4}$.

The idea of 'communitarianism' can occasion confusion in an African moral tradition. It can be understood either as a cultural claim or even as a metaphysical claim. I think Wiredu has this sense of a culture when he avers that:

"To adjust the interests of the individual to those of the community is not to subordinate the one to the other. The relationship is a purely symmetrical. We could just as well have described it as the adjustment of the interests of the community to those of the individual. Moreover, we must not hypostatize the notion of the community. The community is simply a certain contextualization of individuals with respect to their locations and to their perceptions of their interests and of those of others. Communitarianism and individualism are both just different ways of arranging the pursuit of the interests of individuals." (Wiredu, 2008: 334)

The point of this long passage is simply to observe that different cultures organize themselves differently in pursuing human interests. Some cultures put emphasis on the individual and others put it on the community. 
At this level, it would be hasty or even misguided to seek to judge one cultural system as better than the other. At this level of differentiating cultures, we are engaged in a metaphysical or descriptive analysis, where we are merely distinguishing different forms of organizing to pursue individual interests. This distinction is appositely captured in the debate between liberals and communitarians in the Western tradition. To say liberalism is 'individualistic' is to make a metaphysical claim about how they understand the relationship between an individual and society, where the individual is understood in terms of an analogy of an atom entailing that she is understood to be existing prior and independent of the community. And, 'communitarianism' insists that an individual cannot be understood outside of the communal relationships that (partially) constitute her. The debate at this level is not normative; it is simply metaphysical about the nature of an individual and her relation with the community, whether it is essential or contingent (Neale \& Patrick, 1990).

In this article, I am interested in more than these metaphysical claims about socialization and personal identity. By 'communitarianism' I have in mind the view that morality ought to be accounted for purely in terms of some relationship rather than some feature of an individual. The following quotations capture this kind of understanding of morality. For example, Muxe Nkondo (2007: 90) avers that "the supreme value of society, the primary importance of social or communal interests, obligations and duties over and above the rights of the individual". Or, Desmond Tutu's claim that "Harmony, friendliness, community are great goods. Social harmony is for us the summum bonum - the greatest good" (Tutu, 1999: 35, emphasis mine). Or, Ifeanyi Menkiti's assertion that "...In the African understanding, priority is given to the duties which individuals owe to the collectivity, and their rights, whatever these may be, are seen as secondary to their exercise of their duties" (Menkiti, 1984: 181, emphasis mine).

These thinkers converge on the idea that morality somehow is not something we owe directly to individuals because of some feature they possess. Instead, they appear to be grounding morality on some social relationship. Metz's understanding of African moral thought has come to be one of the leading defenders of this kind of normative communitarianism, where some relationship(s) is made the basic carrier of value. Note how Metz (2007: 333) represents this position. Metz begins by drawing the distinction about where to ultimately locate value: "one might morally value something about people as they are in themselves or 
as being part of certain relationships". The word 'or' is to point to the dichotomy that Metz has in mind: a moral theory is either based on individualistic considerations as fundamental or it is based on some relationship as primary. One either has a monistic individualistic or communitarian moral theory. Metz is unequivocal that he defends a strictly relational theory:

"A different understanding of the morality of ubuntu includes the idea that moral value fundamentally lies not in the individual, but rather in a relationship between individuals." (Metz, 2007: 333)

In the same page, he comments:

"The idea that interpersonal relationships of some kinds have basic moral status is not often found in Anglo-American or Continental normative theory.

So from the above, we can reasonably draw a distinction between individualistic and communitarian (relational) accounts. The distinction should be understood in terms of where to ultimately locate moral value: (1) some individual property or some interpersonal relationship(s).” (Metz, 2007: 333)

An example might be useful to illustrate this distinction. Imagine a case of a drowning child. One can have two sorts of reasons to explain her decisions to save her. On an individualistic account, one would be saving her for reasons pertaining to the fact that she has a soul, welfare or dignity. The individualistic explanation invokes some property internal to her to ground why she is saved. A communitarianism account will invoke considerations external to the individual to explain why she is saved like she is my brother or any other type of a relationship. In the next section, I roughly consider the works of influential scholars of African moral philosophy to indicate that they ultimately defend moral individualism.

\section{INDIVIDUALISM IN AFRICAN MORAL THOUGHT}

There is no question that Kwasi Wiredu and Kwame Gyekye are one of the most influential moral thinkers in African philosophy. Interestingly both of them defend humanism (Molefe, 2015). 'Humanism' is a metaethical thesis about the nature of moral properties, that they are best understood in natural terms, specifically, some human property (Wiredu, 1992; Gyekye, 1995). To support humanism, Wiredu (1992: 194) invokes this Akan maxim: "onipa na obia" and he interprets it to mean "all human value derives from human interests". In another place he notes that "the 
first axiom of all Akan axiological thinking is that man or woman is the measure of all value" (1996: 65). It is abundantly clear that Wiredu's moral theory is individualistic. To defend humanism as a meta-ethical theory and to posit buman interests or well-being as the basic moral norm settles the question that Wiredu's moral theory is thoroughly individualistic.

The same can be said about Gyekye's moral theory. He is also a humanist and this implies that he has to ground morality on some human property since he rules out God, in some sense, from morality (Gyekye, 2010). Gyekye unequivocally states that "all other values are reducible ultimately to the value of well-being ... all things are valuable insofar as they enhance ... well-being ... as a "master value"' (Gyekye, 2004: 41). So, Gyekye like Wiredu grounds his moral theory on an individualistic property of well-being; he calls this value the master value. All other values matter only secondarily, and well-being is foundational. So, here, we see two influential moral thinkers who defend a humanistic meta-ethics that locates morality in some human property. So, Akan morality as represented by these two influential African philosophers is individualistic as it grounds morality in some human property, specifically, well-being.

One might hastily suppose that individualism will obviously only saliently be a feature of humanistic meta-ethics, but the case will be different for African moral scholars who defend a religiously founded morality. In fact, even influential theologians and philosophers who take a religious orientation to African ethics equally appear to endorse individualism. For example, take influential theologians in an African tradition like Laurenti Magesa, Benezet Bujo, Augustine Shutte and Godfrey Onah, among others; all these ground morality on some intrinsic property of life or vitality. For example, Magesa states that the aim of ethics is to "enhance the life force of the human person and the society" or "the sole purpose of existence ... is to seek life" (Magesa, 1997: 81 \& 52). Or, Bujo states: "The main goal of African ethics is life itself ... The life which issues from God becomes a task for all human beings ..." (2001: 88; see also 1998: 27). In the same book he states that "life is the highest principle of ethics" (Bujo, 2001: 2-3). One will do well to remember that this talk of vitalism is reminiscent of Placide Tempels analysis of African metaphysics, which is grounded on the property of vitality. Tempels $(1959: 30,32)$ states of Bantu people's “... purpose is to 
acquire life, strength or vital force ... Each being has been endowed by God with a certain force, capable of strengthening the vital energy of the strongest being of all creation: man...".

So, these are religious moral theories since the reference to 'life' or 'vitality' is a reference to a divine property (Shutte, 2001). It is how individuals relate to this individualistic property of life that becomes the primary focus of morality. For example, Gyekye's normative theory takes a consequentialist frame insofar as it requires us to promote individual wellbeing but these three religious thinkers may be construed to be defending a self-realization approach to ethics, which requires agents' to grow or preserve their vitality by way of perfecting their characters or so I understand them (Bujo, 2001: 88; Shutte, 2001: 14).

From the above consideration, we see that among both the secular and religious approaches to ethics a tendency to take individualism as a hallmark of moral theorization in an African tradition. It is for this reason that the following remarks by Metz are not surprising:

"It is a banality to say that dominant Western moral views are « individualistic » and African ones are "communitarian", and so it is odd that the most common theoretical interpretations of ubuntu, which I have explored above, are all more the former than the latter." (Metz, 2007: 333)

As I have demonstrated above, much of African moral accounts we just considered take individualism as a frame within which to articulate morality. The 'odd' state Metz notices is as a result of colleagues being less than careful and thorough when they do their moral theorization and this has tended to represent communitarianism in less than perspicuous terms and this has also added to making it less plausible than it could be (Masolo, 2004). If this prima facie evidence is anything to go by then it raises a crucial question about why then call these theories 'communitarian' if they are essentially individualistic. The purpose of this article is not to answer this relevant and pressing question, but to reveal the individualism that characterizes African moral thought. But, a comment or two would dispel much confusion in the literature.

I suppose these theories are rightly termed 'communitarian' insofar as they posit some relationship(s) as the only effective means for achieving the good that belongs to the individual qua individual be it well-being or life. This point is well captured by Godfrey Onah when he states:

"At the centre of traditional African morality is human life. Africans have a sacred reverence for life... To protect and nurture their lives, all human beings are inserted 
within a given community... The promotion of life is therefore the determinant principle of African traditional morality and this promotion is guaranteed only in the community. Living harmoniously within a community is therefore a moral obligation ordained by God for the promotion of life." (Cited in Metz, 2007: 329).

Here, taking life as the basic moral good (individualism), Onah proceeds to inform us that to secure, promote or nurture it, the human community is decisive. The goal of ethics is to promote life but that goal can only be guaranteed by the community. Hence, relationships in this ethical approach are thought to be the only best means to achieve the moral goals entailed by individualism. Put more succinctly, individualism tell us that some property is the basis for understanding the chief moral goal of morality be it life or welfare; and, then communitarianism refers to the instrumental good i.e. the means necessary for achieving such a goal. Life is intrinsically good and the community is instrumentally good for securing the goal of morality. It is this insistence on the community as the only vehicle to achieve the moral goal of securing some individual good that makes African thought communitarianism or at least I recommend that is how we should understand it.

For example, Utilitarianism will differ from this kind of communitarianism because someone in some remote room pressing a button that produces the greatest good for the greater number would be considered to be acting morally, but not so in an African tradition. One can only realize the moral good by some kind of interaction or relationship with others as the necessary feature of promoting individual morality. It is this element of relationships as instrumentally good that is decisive in accounting for the communitarian status of African ethics. In the next section, I proceed to provide what I consider to be more concrete evidence that African moral thought is best construed in terms of individualism, by considering two ethical concepts that are central to moral theorization in this tradition: personhood and dignity.

\section{PERSONHOOD AND INDIVIDUALISM}

I begin my analysis by considering the notion of personhood in an African tradition. This notion may be used either ontologically or normatively (Ikuenobe, 2006; Molefe, 2016). Ontological accounts of personhood elucidate a theory of human nature i.e., they explain the features that constitute human nature be it the body, mind and/or soul 
and so on. African scholars inform us however that normative considerations are "germane" or "more dominant" in this tradition (Ikuenobe, 2006: 117; Wiredu, 2009: 13). Behrens informs us that "there is an African conception of personhood that is not only distinct from Western notions, but is also foundational and characteristic of African philosophical thought" (2013: 105). This notion we are told that it is distinct from what one usually finds in the West. We are also informed that it is both foundational and characteristic of African philosophical thought. It is therefore unsurprising that Metz's survey of the literature in African ethics indicates that "This is probably the dominant interpretation of African ethics" (2007: 331). It is equally important to note that African scholars tell us time and again that the best way to make sense of communitarianism is through this very notion of personhood (Gyekye, 1992: 102; Gyekye, 1997: 49; Mbigi, 2005: 75; Wiredu 2008: 336).

Furthermore, influential scholars of African ethics converge on the idea that personhood entails a self-realization ethical theory (Van Niekerk, 2007; 2013; Lutz, 2009; Molefe, 2017a). For example, Shutte states:

"The moral life is seen as a process of personal growth... Our deepest moral obligation is to become more fully human. And this means entering more and more deeply into community with others. So although the goal is personal fulfilment, selfishness is excluded." (Shutte, 2001: 30)

The goal of morality is for an agent to be fully human, which is understood in terms personal growth. So, a self-realization approach to morality posits perfection of an agent as the proper goal of morality (Van Niekerk, 2007). Or, put in the parlance of personhood, one is expected to go beyond merely being an animal by developing moral characters imbued with moral virtue (Gyekye, 2010). Or, in the famous words of Menkiti "For personhood is something which has to be achieved, and is not given simply because one is born of human seed" or "As far as African societies are concerned, personhood is something at which individuals could fail, at which they could be competent or ineffective, better or worse... [so the goal is to convert] what was initially biologically given... to attain social self-hood, i.e., become a person with all the inbuilt excellencies implied by the term" (1984: 172-173). So, the term 'person' is used ethically to refer to a human being that is characterized by moral excellence or moral virtue (Wiredu, 2009; Behrens, 2013).

This idea of personhood thus represents a moral identity or even status a moral agent achieves as her character manifests virtues befitting 
a genuine human life. If personhood refers to what the agent achieves then this ethical term is patently individualistic; the goal is perfecting something in the individual, her own humanity or some facet of it (Metz, 2007: 330-331). And, this individualistic feature of this moral term occurs to African thinkers but they do not emphasize it largely because they are absorbed by a misunderstanding of the project communitarianism (Gyekye, 1997; Masolo, 2004).

Even in this approximation, scholars do not notice the individualist nature of this ethical term of personhood. Elsewhere, I have argued at length that if this ethical term posits self-realization as the proper goal of morality then it is a partialist in its orientation (Molefe, 2017b; see also Van Niekerk, 2007: 364). Put differently, one is expected to perfect her own humanity in a way that she is not expected to do for another. The goal of morality is not to the community itself for its own sake, as an end; no, the goal of morality is the individual herself, as an end. Her entering more and more into the community, as Shutte opined above, is merely as a means to achieve the goal of a self, which is perfection. It is for this reason that Jason van Niekerk thinks this ethical term renders African ethics to be "autocenntric" insofar as it is about the self (auto) centring all efforts to perfect itself by engaging with others positively in relationships $(2007 ; 2013)$. One can better appreciate the partiality that characterizes this ethical term of personhood qua self-realization moral theory by thinking about it in terms of reasons for acting.

One's reasons for acting can either be agent-neutral or agent-centred (MacNaughton, 2006). 'Agent-neutral' reasons are those that make no reference at all to the agent or her special relationship in its quest to secure the good. The moral agent acts from an impartial standpoint. Actutilitarianism is agent-neutral in this sense: a moral agent is expected to promote the general good of anyone or even everyone since the interests of all count equally one cannot prioritize herself or special relationships (Rachels \& Rachels, 2015). 'Agent-centred' reasons are those that make an essential reference to the agent as part of the moral explanation for why she acts in the way she does. If two people are burning in a fire and one is my family member; the reason why I saved my family member is merely informed by the fact that she is my family member.

Thus, the reason why I pursue personhood as the moral goal is mostly because it is good for me to be perfect or to lead a fuller human life. The reasons involved are essentially about me as an agent and not so much the community important as it might be, in some sense. Metz reveals 
clearly the agent-centred nature of this idea of person, in his criticism of it as a self-realization account. He submits: "If I ask why I should help others, for example, this theory says that the basic justificatory reason to do so ... is that it will help me by making me more of a mensch or a better person" (Metz, 2007: 332). In situations involving, for example altruism, Metz notes that this account would not give a plausible explanation for why I helped that beggar at the corner. Metz holds the view that part of the explanation for helping poor people must involve less-or-no reference to me as the focus, but it must be riveted on the beneficiary, the patient. But, Metz notes that it is in the very make-up of this ethical term that the reasons that flow from it have to be intransigently agent-centred. I am not interested in evaluating this critique, I think however it rightly identifies the individualistic facet of this moral theory as demonstrated by its partialism that focuses on the self as the proper focus of morality.

Thus, if it is true that the idea of personhood is central in African moral thought then it follows that it offers an individualistic understanding of African ethics. To say it is individualistic, it is to point to the fact that it locates ultimate value, not in the community or some relationship, but in some feature intrinsic to an individual. Above, I argued that the ethical term of personhood characteristic of Afro-communitarianism is essentially individualistic. This individualism, I noted, manifests itself in both the goals set by this ethical term and by the reasons it offers for moral actions. The proper goal of morality is for an agent to realize her own true self - this goal of morality points back to the self as the proper focus of morality. In terms of reasons for acting, we noted that they are also rooted on the agent prioritizing herself. She acts the way she does largely because it is good for her. Thus, we can conclude that this ethical term is overtly individualistic.

It may be objected that people like Menkiti thought of this term in communitarian terms. For example, Menkiti (1984: 172), who is credited with being the first to adumbrate this normative notion of a person in an African tradition, notes that it is a processual notion that requires that one be incorporated "into this or that community" and without this kind of community incorporation one would be considered a "mere dangler" (Wiredu, 2004: 17). And, again, in the same passage, Menkiti notes that in "this long process of attainment (of personhood), the community plays a vital role as a catalyst and the prescriber of norms".

The ineffectual nature of such an objection should be immediately appreciated. No one denies the importance of the community as a catalyst 
and as a prescriber of norms for evaluating whether one is leading a genuine or a true human life. I agree with Menkiti understanding of the role of the community. And, admitting this kind of the role played by the community does not amount to denying individualism. Ultimately, it is the individual effort that makes all moral the difference to whether one leads a good life or not. If that job of achieving personhood was largely attributable to the community then we would struggle with holding individuals accountable and responsible; it would even be difficult to judge some human beings as good or bad. So, it is the individual by exerting her moral energies to perfect her character that does all the relevant moral job and the community serves only as a moral incubator. The community, as alluded to before, is merely instrumentally good. The instrumentality of the community is noted by Menkiti when he talks of it as a 'catalyst', which refers to a chemical substance that assists the chemical process by speeding it, for example, without being the focus of the chemical process or even its goal. As the prescriber of norms, the community sets cultural or normative standards; but it is individuals who live by those stands and who are equally judged by the same, some meeting them and some not. Below, I consider the idea of dignity to further buttress the point that African ethics is individualistic.

\section{DIGNITY AND INDIVIDUALISM}

The ideas of dignity and human rights have a currency in global moral political discourse (Donnelly, 1982a; 2009). This idea of dignity also holds an established place in African moral political thought (Donnelly, 1982b; Gyekye, 1992; Deng, 2005; Ramose, 2009). 'Dignity' is a moral doctrine that attaches intrinsic worth to human nature per se. In other words, the mere fact of being human marks one out as a bearer of special moral features and thus deserving utmost respect (Donnelly, 2009; Toscano, 2011). One has dignity merely because they are human, it is not earned (George and Lee, 2008). This idea is important in moral discourse because it secures the equality of all human beings (Dworkin, 1977).

It is important also because of its deontic restrictions i.e. it serves as a normative constraint over what means we may not use when seeking promote the good (Toscano, 2011). In other words, certain ways of promoting the good are wrong because they fail to regard the high respect due to a human being merely because she is a human being. This means, all things being equal, I may not kill another human being for the 
sake of improving the lives of other human beings. A human qua human ought to be respected irrespective of what great global moral goals one may have in mind.

To limit the potential danger inherent in the fascination or even fixation with the collective good as is common in African thought, Gyekye invokes this idea of dignity (1992: 114). In this light, Gyekye notes: "the reason is that the natural membership of the individual person in the community cannot rob him of his dignity or worth, a fundamental and inalienable attribute he possesses as a person". Here, it is clear that Gyekye understands dignity like the rest of other thinkers as a fundamental or inalienable property of human nature. For Gyekye, dignity is so fundamental that it is one of the central considerations when setting up or even evaluating a moral political project. He erects his theory of communitarianism precisely to challenge radical communitarianism that he thinks undermines this fundamental property that marks out a human being as a being of inherent worth. Gyekye is not alone in this project of taking dignity seriously.

Another influential thinker of African moral thought in South Africa, Mogobe Ramose, invokes this idea of dignity. Ramose reminds us that dignity captures the "importance of the individual human being". In another place, he notes: "The first is that the individual human being is an object of intrinsic value" (Ramose, 2009: 420). To signify the centrality of this idea below the Sahara, Ramose appeals to this Sotho aphorism: "feta kgomo o tshware motho". And, he proceeds to comment on it in thus:

"This means that if and when faced with a decisive choice between wealth and the preservation of the life of another human being, then the choice should be to preserve another life." (Ramose, 2009: 420)

This choice is informed by the fact that a human being is a bearer of dignity. He concludes by noting the importance and decisive nature of the status of human beings as bearers of dignity.

These are by no means the only scholars who consider this idea of dignity to be central in African thought. In fact, there is a general consensus in African axiological system that a human being is a being of high value. Scholars might differ in their conceptions of dignity, but I am not aware of a salient scepticism of this concept in an African tradition. If this idea of dignity is truly an important facet of Afro-communitarian moral thought then it follows that this is another individualistic feature 
that is part of the architecture of African moral thought. So, here we see that prominent moral terms in Afro-communitarian thought are essentially individualistic.

Two possible objections that may be raised against my defence of individualism. One argument might straight away jettison the claim that these two or even one of them is central to African thought. I doubt that many African scholars will find this to be a worthwhile move in Afrocommunitarian thought since one will be denuding African axiological considerations of some of its essential furniture ${ }^{7}$. The second strategy is to propose a plausible relationship theory as a counterexample to my argument. It is this kind of objection that I turn.

\section{OBJECTION: METZ'S RELATIONALISM}

The objection that can be derived from Metz's moral theory is that my argument that individualism is a plausible feature of Afro-communitarianism is not true since he defends what he considers to be a plausible relational theory (2007: 321), so much that he thinks this relational theory should be taken as seriously as other influential global moral theories from the West like utilitarianism (2014). It is worth noting that the global influential moral theories that Metz thinks his relational theory should be taken as seriously as much as they are taken, are individualistic. In an important way, Metz seeks to defend the dominant view that African moral theories are communitarian (relationship-based) and Western ones are typically individualistic.

I do not think this kind of objection really works against my argument that defends individualism as a feature of communitarian moral theories. I do not deny that Metz defends a novel relationalist interpretation of African moral theory. I deny however that his relationalism is plausible. This is by no means to suggest that we may not gain worthwhile moral insights about African moral thinking and morality in general from his moral theory. I personally have learnt a lot from Metz's moral theorization in the African tradition and the tradition of African philosophy has greatly benefitted from his work. I however remain unconvinced about its plausibility. Elsewhere, I have argued extensively that the monistic relational theory of Metz has features that render it implausible (Molefe, 2017c). I here reject the theory not on the basis of its incoherence, but I simply urge Metz to make up his moral-theoretical mind about whether he is committed to relationalism or individualism. 
I say so because when Metz defends a theory of right action, he insists on defining it entirely in terms of some interpersonal relationship. But when he defends a conception of dignity, he invokes individualism. So, a close reading of Metz's moral corpus has this fundamental tension of defending both relationalism and individualism at the same time. Metz is aware of this disjuncture between these two disparate interpretations of African ethics in his moral philosophy. With regards to a relational account, Metz avers:

"U: An act is right just insofar as it is a way of living harmoniously or prizing communal relationships, ones in which people identify with each other and exhibit solidarity with one another ..." (Metz, 2010: 84)

And, with regards to an individualistic account, Metz opines:

"U2: An act is wrong ... because it degrades the individual's dignity that she has in virtue of her capacity to engage in harmonious relationships..." (Metz, 2010: 94)

It is crucial for the reader to note these two disparate ways to account for a theory of right action. The relationalist account $(\mathrm{U})$ defines a right action in terms of respecting some interpersonal relationship of friendship, but the individualist one (U2) in terms of respecting a person's capacity for relationships. One grounds morality on some external consideration and the other on some internal one.

After noting this disjuncture in these two possible ways to account for morality, Metz proceeds to make the comment that holds my defense together:

"I am as yet unsure of how $\mathrm{U} 2$ and $\mathrm{U}$ precisely relate to one another, specifically, of whether they are ultimately equivalent, whether $\mathrm{U} 2$ is more fundamental than $\mathrm{U}$, or whether they need to be combined in some way." (Metz, 2010: 94)

So, this is evidence enough that Metz is yet unsure about whether U2 (theory of dignity) is more fundamental than (U) (a relational theory of right action). I here submit that until Metz makes up his mind about which theory is more fundamental, the relational or individualistic account, appeal to his relational account to object to my defence of individualism in African ethics remains moot.

Even more, I wish to highlight that Metz's indecision with regards to relationalism and individualism is not a simple philosophical problem to solve. The problem lies precisely in my second argument for why individualism is a crucial feature of all morality including Afro-communitarianism: the idea of dignity. There is no way to go around a theory of 
dignity and its essential individualism. It is either Metz's moral theorization will forever be characterised by this indecision with regards to either relationalism or he will prefer individualism. If he is truly committed to the idea of dignity as his writings suggest then it seems then he may have to jettison relationalism, a route that appears highly unlikely (Metz, 2010, 2011, 2012). So, as things stand, we are stuck with this indecision; thus securing my position that this objection is not sufficient to unsettle my defence of individualism.

\section{CONCLUSION}

In this article, I sought to defend an ambitious argument that African moralities are more individualistic than African scholars have being willing to admit. To secure this radical claim, I invoked prima facie evidence by considering salient ethical writings from both secularist and religious theorist in the African tradition. I proceeded to provide what I consider to be more concrete evidence from the two central ethical concepts in the African tradition: personhood and dignity. I argued that these ethical notions are essentially individualistic. I concluded the article by considering a major objection that can be made against my argument that defends relationalism in African ethics. I demonstrated that this argument is far from convincing because of Metz's indecision between relationalism and individualism.

\section{Notes}

${ }^{1}$ In this article, I use the word 'African' in the way it is usually used by moral philosophers in an African tradition (See, Metz, 2007; Gyekye, 2010). For example, Gyekye (2010) opines: “Thus, in this entry, the term 'African ethics' is used to refer both to the moral beliefs and presuppositions of the sub-Saharan African people and the philosophical clarification and interpretation of those beliefs and presuppositions"

${ }^{2}$ Here, I am not studying African cultures anthropologically to determine what they actually believed in terms of morality, that would largely be an empirical or a social science endeavor. This is a moral philosophical project that weighs on the literature on African ethical thinking to defend its interpretation of African moral culture by relying strictly on argument.

${ }^{3}$ I do so for an obvious reason. Much of the Western moral literature takes individualism as their frame of moral theorization (see, Metz, 2014). Though there are deviations to individualism, they are not salient.

${ }^{4}$ Surely relationships figure in this moral process, but not as basic moral considerations for accounting for right and wrong. 
5 This understanding of communitarianism is not under scrutiny and is banally true. Metz's (2014: 315): "First, they cannot be sensibly construed as defining elements of communitarianism since they are sociological banalities that no one would reasonably reject. Much too often in the literature, communitarians believe they are targeting liberalism and other 'individualist' philosophies by noting that individuals cannot exist or flourish on their own. However, I am simply not aware of any influential Western, liberal or individualist thinker who has claimed that it is possible for, say, a baby to grow up into a normal adult without socialisation, or an adult to make substantial achievements as a Robinson Crusoe on a deserted island without a cultural tradition, emotional support, substantial resources, peer recognition and so on. Who has made, or would make, such patently false empirical claims?"

${ }^{6} \mathrm{I}$ omit yet another weak objection that this account is Western rather than African since it defends individualism. I relegate this objection to a footnote because I think it begs the question. I am here arguing that all morality is individualistic but specifically focusing on African ethics. A stronger objection, one that is non-question-begging, would have to provide independent evidence to demonstrate that African ethics is not. A task I consider daunting for the detractor.

7 I am comfortable with the move that conceives of dignity as a universal term rather than African. It supports my argument that all morality is individualistic.

\section{References}

Behrens, Kevin. African Philosophy, Thought and Practice and Their Contribution to Environmental Ethics. Johannesburg: University of Johannesburg, 2011.

Behrens, Kevin. "Two Normative Conceptions of 'Personhood"'. Quest 25, 2013: 103-119.

Bujo, Bujo. The Ethical Dimension of Community: The African Model and the Dialogue between North and South. Translated by C. Namulondo. Nairobi: Pauline's Publications Africa, 1998.

Bujo, Bujo. Foundations of an African Ethic: Beyond the Universal Claims of Western Morality. New York: The Crossroad Publishing Company, 2001.

Darwall, Stephen. “Two Kinds of Respect". Ethics 88, 1977: 36-49.

Deng, Francis. "Human Rights in the African Context". Companion to African Philosophy, ED. Wiredu, K. Oxford: Blackwell Publishing, 2004, 499-508.

Donnelly, Jack. "Human Rights and Human Dignity: An Analytic Critique of NonWestern Conceptions of Human Rights". The American Political Science Review, 76, 1982a: 303-316.

Donnelly, Jack. "Human Rights as Natural Rights". Human Rights Quarterly 4, 1982b: 391-405.

Donnelly, Jack. Human Dignity and Human Rights. Denver: Josef Korbel School of International Studies, 2009.

Famanikwa, Jonathan. "How Moderate is Kwame Gyekye's Moderate Communitarianism?" Thought and Practice: A Journal of the Philosophical Association of Kenya 2, 2010: 65-77.

George, Robert \& Lee, Patrick. "The Nature and Basis of Human Dignity. In the President's Council on Bioethics". Human Dignity and Bioethics Essays Com- 
missioned by the President's Council on Bioethics, Ed. K. Kwasi, Washington DC: President's Council on Bioethics, 2004: 409-433.

Gyekye, Kwame. "Person and Community in African Thought". Person and Community: Ghanaian Philosophical Studies, 1, Washington DC: Council for Research in Values and Philosophy, 2004: 101-122.

Gyekye, Kwame. Tradition and Modernity. New York: Oxford University Press, 2004.

Gyekye, Kwame. Beyond Cultures: Perceiving a Common Humanity, Ghanaian Philosophical Studies. Accra: The Ghana Academy of Arts and Sciences, 2004.

Gyekye, Kwame. "African Ethics". The Stanford Encyclopaedia of Philosophy. 2010. Available at: http://plato.stanford.edu/archives/fall2011/entries/african-ethics (Accessed 16 January 2013).

Ikuenobe, Polycarp. "The Idea of Personhood in Chinua Achebe's Things Fall Apart'. Philosophia Africana 9, 2006: 117-131.

Ilesanmi, Simeon. "Human Rights Discourse in Modern Africa: A Comparative Religious Perspective”. Journal of Religious Ethics 23, 2001: 293-320.

Kaphagawani, Didier. "African Conceptions of a Person: A Critical Survey". Companion to African Philosophy, Oxford: Blackwell Publishing, 2004: 332-442.

Kymlicka, Will. Contemporary Political Philosophy: An Introduction. Oxford: Clarendon Press, 1990.

MacNaughton, David \& Rawling, Piers. "Deontology". Oxford Handbook of Ethical Theory, Copp, D Oxford: Oxford Press, 2006: 425-458.

Magesa, Laurenti. African Religion: The Moral Traditions of Abundant Life. New York: Orbis Books, 1997.

Masolo, Dismass. "Western and African Communitarianism: A Comparison". Companion to African Philosophy, Oxford: Blackwell Publishing, 2004: 483-498.

Masolo, Dismass. Self and Community in a Changing World. Indianapolis: Indiana University Press, 2004.

Matolino, Bernard. "Radicals versus Moderates: A Critique of Gyekye's Moderate Communitarianism". South African Journal of Philosophy 28, 2009: 160-170.

Mbigi, Lovemore. The Spirit of African Leadership. Randburg: Knowers, 2005.

Menkiti, Ifeanyi. "Person and Community in African Traditional Thought". African Philosophy: An Introduction, Ed. R. Wright. Lanham: University Press of America, 1984: 171-181.

Metz, Thad. "Toward an African Moral Theory". The Journal of Political Philosophy 15, 2007: 321-341.

Metz, Thad. "Human Dignity, Capital Punishment and an African Moral Theory: Toward a New Philosophy of Human Rights". Journal of Human Rights 9, 2010: 81-99.

Metz, Thad. "Ubuntu as a Moral Theory and Human Rights in South Africa". African Human Rights Journal of Law 11, 2011: 532-559.

Metz, Thad. "An African Theory of Moral Status: A Relational Alternative to Individualism and Holism". Ethical Theory and Moral Practice: An International Forum 14, 2012: 387-402.

Metz, Thad. "Harmonizing Global Ethics in the Future: a Proposal to Add South and East to West". Journal of Global Ethics 10, 2014: 146-155. 
Molefe, Motsamai. “A Rejection of Humanism in African Moral Tradition". Theoria 62, 2015: 59-77.

Molefe, Motsamai. "Revisiting the Debate Between Gyekye-Menkiti: Who is a Radical Communitarian". Theoria 63, 2016: 37-54.

Molefe, Motsamai. "Personhood and Rights in an African Tradition". Politikon 2017(a): 1-17. (http://dx.doi.org/10.1080/02589346.2017.1339176).

Molefe, Motsamai. "An African Perspective on the Partiality and Impartiality Debate: Insights from Kwasi Wiredu's Moral Philosophy". South African Journal of Philosophy. 36, 2017(b): 470-482.

Molefe, Motsamai. "Relational Ethics and Partiality: A Critique of Thad Metz's 'Towards an African Moral Theory"'. Theoria 64, 2017(c): 43-61.

Murove, Felix. "An African Commitment to Ecological Conservation: The Shona Concepts of Ukama and Ubuntu". Mankind Quarterly 45, 2004: 195-225.

Neal, Patrick \& Paris, David. "Liberalism and the Communitarian Critique: A Guide for the Perplexed". Canadian Journal of Political Science 23, 1990: 419-439.

Nkondo, Muxe. "Ubuntu as a Public Policy in South Africa: A Conceptual Framework". International Journal of African Renaissance Studies 2, 2007: 88-100.

Rachels, James \& Rachels, Stuart. The Elements of Moral Philosophy. Boston: McGraw Hill, 2015.

Ramose, Mogobe. African Philosophy through Ubuntu. Harare: Mond Books, 1999.

Ramose, Mogobe. "Ecology through Ubuntu". African Ethics: An Anthology of Comparative and Applied Ethics, Ed. F. Murove. Pietermaritzburg: University of Kwa-Zulu Natal Press, 2009: 308-314.

Shutte, Augustine. Ubuntu: An Ethic for a New South Africa. Pietermaritzburg: Cluster Publications, 2001.

Tempels, Placide. Bantu Philosophy. Translated by Colin King. Paris: Présence Africaine, 1959.

Toscano, Manuel. "Human Dignity as High Moral Status". The Ethics Forum 6, 2011: 4-25.

Tutu, Desmond. No Future without Forgiveness. New York: Random House, 1999.

Van Niekerk, Jason. "In Defence of an Autocentric Account of Ubuntu". South African Journal of Philosophy 26, 2007: 364-368.

Van Niekerk, J. Ubuntu and Moral Theory. Johannesburg: University Witwatersrand, 2013.

Wiredu, Kwasi. "Moral Foundations of an African Culture". Person and Community: Ghanaian Philosophical Studies, 1, Ed. K. Kwasi \& G. Kwame. Washington DC: The Council for Research in Values and Philosophy, 1992: 192-206.

Wiredu, Kwasi. "Introduction: African Philosophy in Our Time". A Companion to African Philosophy, Ed. K. Wiredu. Oxford: Blackwell Publishing, 2004: 1-27.

Wiredu, Kwasi. "Social Philosophy in Postcolonial Africa: Some Preliminaries Concerning Communalism and Communitarianism". South African Journal of Philosophy 27, 2008: 332-339.

Wiredu, Kwasi. "An Oral Philosophy of Personhood: Comments on Philosophy and Orality". Research in African Literatures 40, 2009: 8-18. 